NAPOLEON and the DARDANELLES 


\section{VERNON J. PURYEAR}

\section{UNIVERSITY OF CALIFORNIA PRESS}

Berkeley and Los Angeles : 1951 


\section{NAPOLEON}

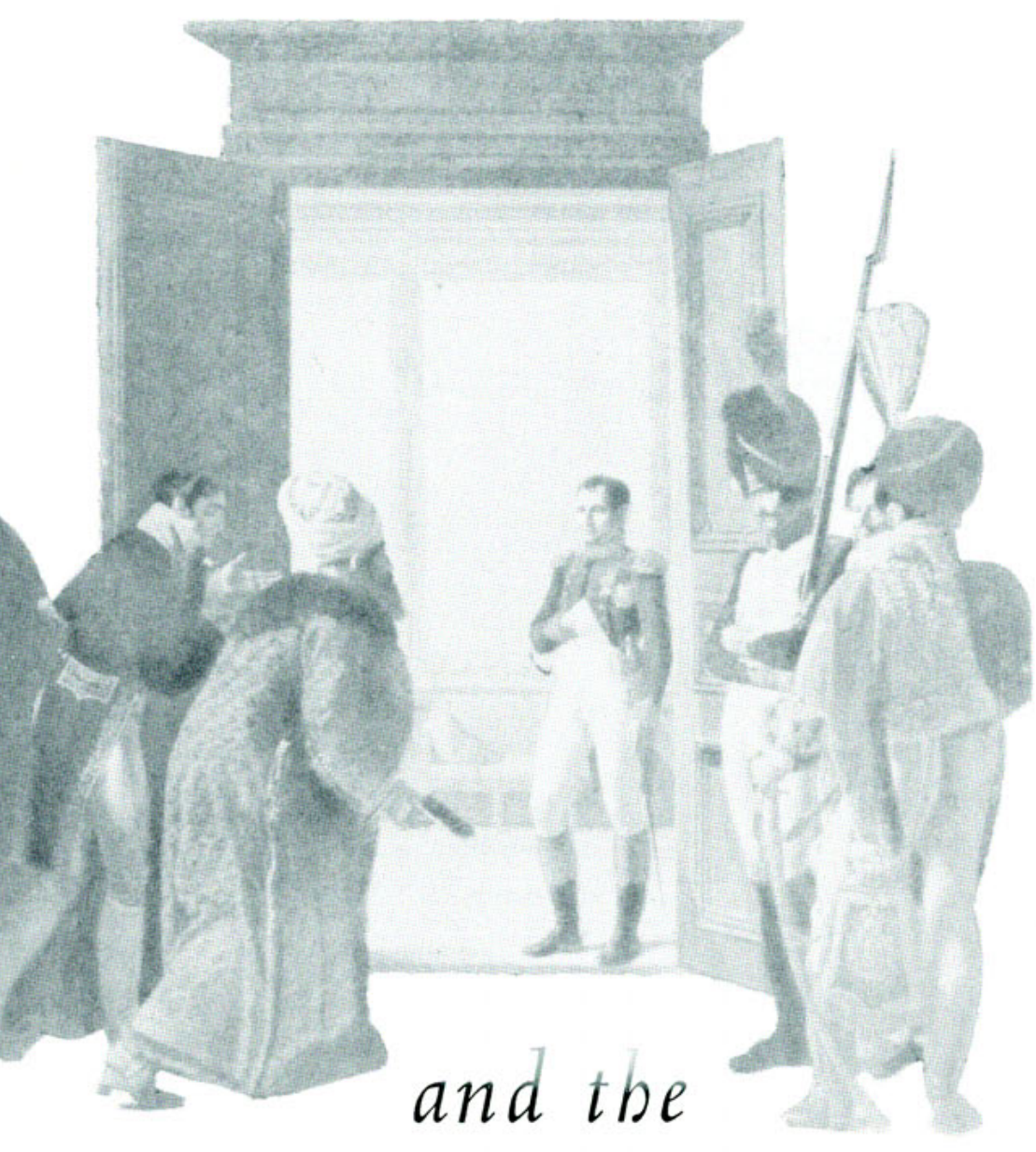

\section{DARDANELLES}




\section{UNIVERSITY OF CALIFORNIA PRESS}

Berkeley and Los Angeles

California

\section{CAMBRIDGE UNIVERSITY PRESS}

London, England

Copyrigbt, 1951, by

THE REGENTS OF THE UNIVERSITY OF CALIFORNIA

The title page shows Napoleon receiving

Persian Ambassador Mirza

at Finkenstein, April 27, 1807.

From the painting by Mulard,

now at the Musée de Versailles. 